\title{
Influence of Physical and Social Factors of Livestock on Duck Farmers' Income and Regional Development: A Case of Rokan Hulu Regency, Riau Indonesia
}

\author{
K. M. Z Basriwijaya, W. Sumekar, T.Ekowati, D.Sunarti
}

\begin{abstract}
Livestock sector plays an important role for regional economy. Physical and social planning is one strategy to spur economic growth, so it must be well planned. The aims for this research were: 1) to study physical and social planning of duck farmers' income; 2) to study development planning. The location of the research was determined purposively because the district was the center of duck farming in Riau. Sampling of 180 farmers was taken using Purposive Sampling. Physical factors consist of population and livestock production while livestock social factors consist of unemployment rate, population of poor people and Human Development Index (HDI). The positive influence of physical and social planning of livestock on the income of duck farmers and regional development was analyzed using path analisys. Based on the results of path analysis, 1. the planning of Human Development Index (HDI), population of poor people, unemployment rate, livestock production and total of duck population have a positive effect on the income of duck farmer 2. Farmer duck income, HDI, population of poor people, unemployment rate, duck production and rate of duck populations have a positive effect on the development of the area in Rokan Hulu. Based on the results of the research, it is recommended that the Rokan Hulu government makes efforts to empower duck farmers in order to increase duck farmer income, to improve the HDI, to reduce population of poor people and unemployed rate, to increase productivity of duck livestock, to absorb labor in the field of duck farming as one indicator of regional development and to make efforts to provide business capital for people's livestock in duck farming.
\end{abstract}

Index Terms: physical and social planning, income of duck farmers, duck production, HDI.

\section{INTRODUCTION}

Livestock development is an effort to improve the welfare of farmers and to encourage the realization of regional economic development through productive activities that are competitive. Utilization of land resources needs to be adapted to the environmental conditions of their livestock (Ardi, 2016) so that livestock farming is sustainable. One approach

Revised Manuscript Received on September 22, 2019

K. M. Z Basriwijaya, Doctorer of Animal Science, Faculty of Animal and Agricultural Sciences,Diponegoro University, Tembalang Campus, Semarang 50275 - Indonesia, zainkiagus@gmail.com

W. Sumekar, Doctorer of Animal Science, Faculty of Animal and Agricultural Sciences,Diponegoro University, Tembalang Campus, Semarang 50275 - Indonesia, wulan_sumekar@yahoo.co.id

T.Ekowati, Doctorer of Animal Science, Faculty of Animal and Agricultural Sciences,Diponegoro University, Tembalang Campus, Semarang 50275 - Indonesia

D.Sunarti, Doctorer of Animal Science, Faculty of Animal and Agricultural Sciences,Diponegoro University, Tembalang Campus, Semarang 50275 - Indonesia that can be done is a parametric approach with a classification system and population division on the basis of commodity characteristics (Abdurrahman, 2010). Livestock development planning is a development process that is intended to make changes towards better development by utilizing available resources (Ekowati, 2005).

According to Halim (2017), planning consists of several components, namely; a) physical planning, which is directed at physical arrangements, in the form of; spatial planning, location of residence and use of livestock land, b) Economic planning related to economic growth, income distribution and productivity, c) social planning, a plan discussing education, health, etc., d. ) Social planning, which is directed at making social development planning in the area. Livestock sector certainly has a strategic role in development because; it will act as an absorber of labors, a staple food producer and even as a determinant of price stability.

Livestock development can be carried out through integrated intensification, extensification, diversification and rehabilitation (integrated farming system) to increase people's income (Nadra., 2018; Janizweski, 2018; Sumekar, 2013). The development of livestock sector can be done through an approach related to several variables. The first variable is physical variable in the form of; selection of superior seeds, housing, management of maintenance of health and disease, and reproduction. The second variable is social variables consisting of labor, education and institutional levels. The third is economic variables in the form of; capital, farmer family income, inflation. The fourth is development variables in the form of; road and irrigation facilities (Yongki, 2016). Agricultural development is a strategy to spur economic growth (Sumekar, 2013) so as to provide a multiplier effect on other sectors, thus the agricultural sector has an important role on the regional economy. For the Rokan Hulu government, this sector has an important role in regional development and development. The sector is able to make a significant contribution to the formation of regional GDP, as in Table 1. 
Table 1. GRDP Growth Rate per Business Field in Rokan Hulu Regency.

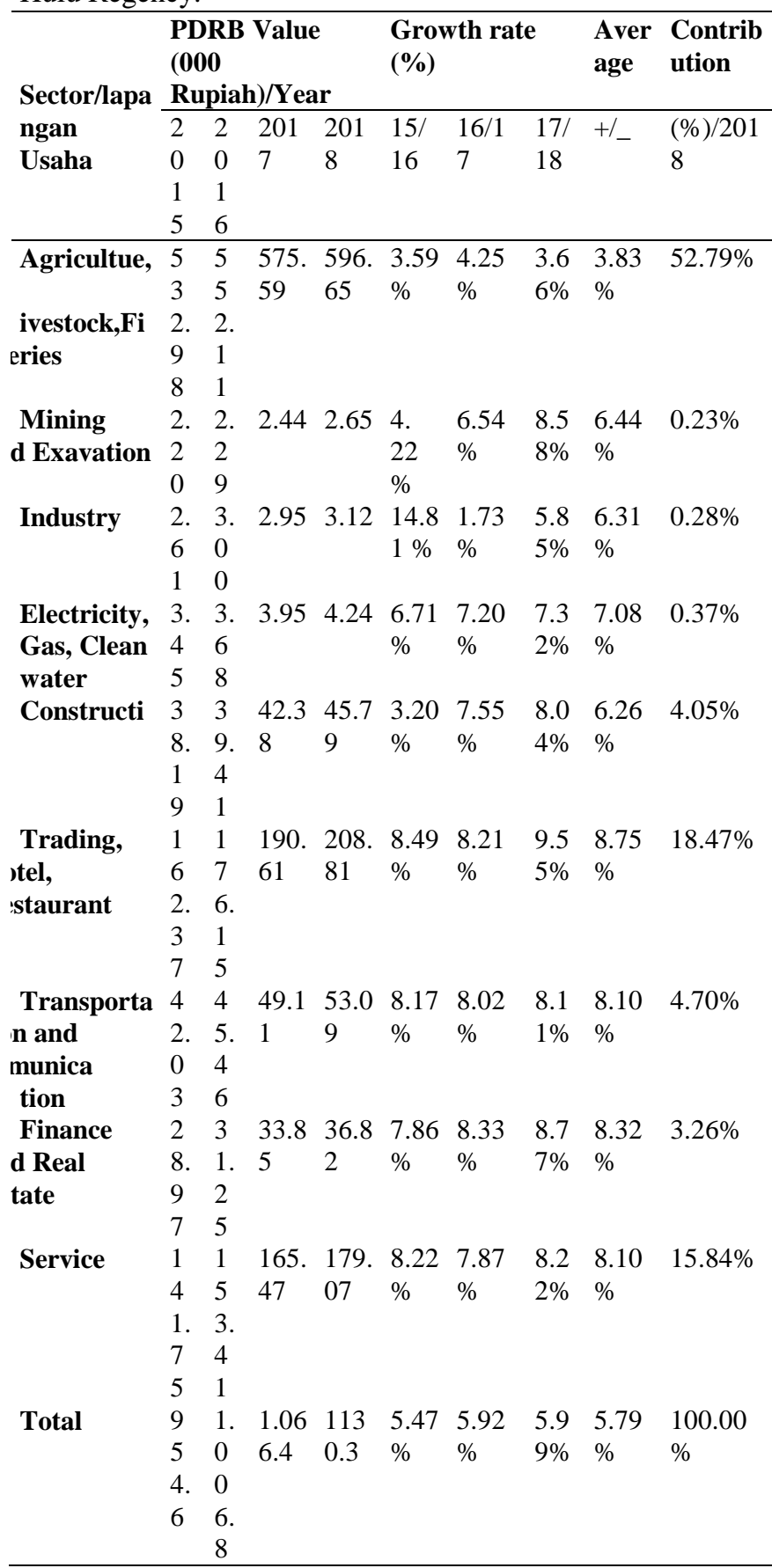

Sumber: BPS, 2018 (diolah)

In Table 1, it can be seen that in 2012, the agriculture/petroleum sector contributed $52.79 \%$ to Rokan Hulu GRDP, with an average growth rate of $3.83 \%$ from 2009 to 2012 . The average growth rate of this sector was smaller compared to the other sectors; mining and quarrying $6.44 \%$, industry $6.31 \%$, electricity, gas, and clean water $7.08 \%$, transportation and communication $8.10 \%$ and other sectors. More details can be seen in Table 1. Based on this background, this research was conducted to analyze, "The effect of physical and social factors on livestock planning to increase community income and regional development in Rokan Hulu District". Based on the background that has been stated, the problems in this study are:

1. How do physical factors, consisting of population and production, and social factors, consisting of unemployment rate, number of poor people and HDI, affect the income of the duck farmer in Rokan Hulu Regency?

2. What is the influence of physical factors, consisting of population and production, and social factors, consisting unemployment rate, population of poor people and HDI, on regional development in Rokan Hulu Regency.

\subsection{Research Purposes}

Based on the background and formulation of the problems described, the objectives of this study are:

1. To analyze the influence of physical factors, consisting of population and production, and social factors, consisting of unemployment rate, population of poor people and HDI, on the income of the duck farmer in Rokan Hulu Regency.

2. To analyze the influence of physical factors, consisting of population and production, and social factors, consisting of unemployment rate, population of poor people and HDI, on regional development in Rokan Hulu Regency.

\section{LITERATURE REVIEW}

\section{A. Physical And Social Factor}

Physical Factor is planning evolving from economic thinking. It is originating from the need to compute limited resources of a large and expanding need. Planning is a building process intended to create changes to improvement by utilizing available resources efficiently and effectively (Welerubun, 2016). According to...., planning comes from the word "plan" which means the design or the framework for doing an action. Planning is an action carried in the future by considering its potential, external factors and interested parties carefully in order to achieve a certain goal (Sumekar, 2013). Planning is used as a parameter to be able to carry out work effectively, successfully and excellently. The form of social factors of planning can be observed through attitudes and skills, but it does not mean that the form of behavior can only be seen from its attitude and justness. Behavior can also be potential, particularly in the form of knowledge (Zurmiati, 2018)

Development planning is series of procedures and stages of making development plans. According to....., there are two forms of development planning models. They are production and social factors. Social factors consist of unemployment rate, total of poor people and HDI (Janizweski, 2018) According to horizontal model, planning can be applied nationally, regionally, and locally. Horizontal planning is the making of plan by analyzing and integrating various aspects of planning at one level. Meanwhile, vertical model (often called sectoral planning) follows a sectoral approach, education, health, and so on. Vertical planning is conducted by analyzing and combining various relevant aspects from various levels (Basriwijaya, 2018).

\section{B. Human Development Index (Hdi)}

HDI explains how people can access the results of development to get income, health, education, and so on. HDI was introduced by the United Nations Development Program (UNDP) in 1990 and is published regularly in the annual Human Development Report (HDR). The HDI is 
based on basic dimensions of life expectancy and healthy life knowledge.Decent living standards of HDI is an important indicator to measure successful effort to build quality of life for people (Abdurrahman, 2010). HDI can develop a regency. HDI is strategic data in Indonesia, because in addition to being a measure of Government performance, HDI is also used as one of the allocators for the determination of the General Allocation Fund (DAU). Some indicators are not appropriate to be used in calculating HDI. Literacy rates are irrelevant in measuring education as a whole because they cannot describe the quality of education. In addition, because literacy rates in most regions are high, they cannot distinguish between levels of education well (Nadra, 2018)

PNB replaces GDP because it better describes the income of duck farmers in a regency. By using geometric averages in composing HDI, it can be interpreted that the achievement of one dimension cannot be covered by the achievements of other dimensions. Therefore, to realize good human development, three dimensions must get the same attention because it is equally important (BPS, 2018).

\section{METHODOLOGY}

\section{A. Location, Research Samples}

The location and sample of this study were determined intentionally (probability sampling) using convenience sampling technique by deliberately selecting samples in accordance with the wishes of the researcher (Basrwijaya, 2018). This research was conducted in Rokan Hulu District, an area which is very potentially agricultural to be developed in the context of regional development.

\section{B. Source And Data Collection}

The data needed in this study are Primary data collected by interviews and secondary data sourced from the Central Statistics Agency (BPS) publications and other official publications.

\section{1) Data Analysis Technique}

Data analysis in this study is path analysis as follows:

1. Physical factors consisting of population and production and social factors consisting of unemployment rate, the number of people living in poverty and HDI affect the income of Rokan Hulu farmers, with the formula as follows:

$\mathrm{Y} 1=\mathrm{PY} 1 \mathrm{X} 1.1+\mathrm{PY} 1 \mathrm{X} 1.2+\mathrm{PY} 1 \mathrm{X} 2.1+\mathrm{PY} 1 \mathrm{X} 2.2+$ $\mathrm{P} 1 \mathrm{X} 2.3$.

2. Physical factors consisting of population, production and social factors consisting of unemployment rate, population of poor people and HDI affect the development of the area in Rokan Hulu Regency, with a formula as follows;

$\mathrm{Y} 2$ = PY1X1.1 + PY $1 \mathrm{X} 1.2+\mathrm{PY} 1 \mathrm{X} 2.1+\mathrm{PY} 1 \mathrm{X} 2.2+$ PY $1 X 2.3+\mathrm{PY} 2 \mathrm{Y} 1$

key :

$\mathrm{Y} 2$ = Regional development (absorption rate of labors).

3. $\mathrm{Y} 1=$ Community income.

4. $\mathrm{X} 1.1=$ total population.

5. $\mathrm{X} 1.2=$ production.

6. X2.1 = unemployment rate.
7. $\mathrm{X} 2.2=$ population of people living in poverty

8. $\mathrm{X} 2.3=\mathrm{HDI}$

9. $\square 1, \square 2=$ residue

\section{RESULTS AND FINDINGS}

The Influence of Physical and Social Factors of Livestock Planning on Farmers Income and Regional Development in Rokan Hulu District. Based on the results of the study, it is known that physical factors and economic factors of livestock planning affect the increase of community income and regional development in Rokan Hulu District, as shown in Table 2.

Table 2. Physical Factors of Planning Livestock Sector in Rokan Hulu District

\begin{tabular}{lllll}
\hline Year & $\begin{array}{l}\text { Total } \\
\text { Population }\end{array}$ & $\begin{array}{l}\% \\
\text { Population }\end{array}$ & $\begin{array}{r}+/- \\
\text { Production }\end{array}$ & $\begin{array}{l}\text { \% } \\
\text { Production }\end{array}$ \\
\hline 2009 & 21.657 & - & 15.427 & - \\
2010 & 22.172 & $2.38 \%$ & 17.446 & $13.09 \%$ \\
2011 & 22.698 & $2.37 \%$ & 18.465 & $6.87 \%$ \\
2012 & 26.531 & $16.89 \%$ & 24.858 & $33.32 \%$ \\
2013 & 26.667 & $0.51 \%$ & 24.994 & $0.55 \%$ \\
2014 & 22.791 & $-14.53 \%$ & 15.396 & $-38.40 \%$ \\
2015 & 21.686 & $-4.85 \%$ & 16.243 & $5.50 \%$ \\
2016 & 23.432 & $8.05 \%$ & 17.311 & $6.57 \%$ \\
2017 & 25.435 & $8.55 \%$ & 18.345 & $5.97 \%$ \\
2018 & 26.251 & $3.21 \%$ & 21.379 & $16.54 \%$ \\
\hline
\end{tabular}

Based on: BPS Rokan Hulu, 2018, Dinas Peternakan Rokan Hulu, 2018 diolah (2019)

In table 2 , it can be seen that population and production as physical factors planning for livestock sector in Rokan Hulu district fluctuated from 2010 to 2018. Furthermore, social factors as variables in planning livestock sector in Rokan Hulu Regency are presented in Table 3.

Tabel 3. Social planning factors of livestock sector in Rokan Hulu District

\begin{tabular}{ccccccc}
\hline Year & $\begin{array}{c}\text { unemp } \\
\text { loymnt } \\
\text { level }\end{array}$ & $\begin{array}{c}\%+/- \\
\text { unemplo } \\
\text { yment }\end{array}$ & $\begin{array}{c}\text { provert } \\
\text { level }\end{array}$ & $\begin{array}{c}\%+/- \\
\text { prover } \\
\text { ty }\end{array}$ & HDI & $\begin{array}{c}\%+/ \\
\text { HDI }\end{array}$ \\
\hline 2009 & 5.92 & - & 28.9 & - & 70.75 & - \\
2010 & 6.75 & $14.02 \%$ & 26.7 & $-7.61 \%$ & 72.98 & $3.15 \%$ \\
2011 & 8.39 & $24.30 \%$ & 24.6 & $-7.87 \%$ & 71.87 & $-1.52 \%$ \\
2012 & 9.27 & $10.49 \%$ & 23.5 & $-4.47 \%$ & 72.34 & $0.65 \%$ \\
2013 & 6.94 & $-25.13 \%$ & 20.4 & -13.19 & 71.24 & $-1.52 \%$ \\
& & & & $\%$ & & \\
2014 & 1.66 & $-76.08 \%$ & 17.7 & -13.24 & 71.64 & $0.56 \%$ \\
& & & & $\%$ & & \\
2015 & 0.69 & $-58.43 \%$ & 18.2 & $2.82 \%$ & 71.94 & $0.42 \%$ \\
2016 & 3.56 & $415.94 \%$ & 17.5 & $-3.85 \%$ & 72.43 & $0.68 \%$ \\
2017 & 0.35 & $-90.17 \%$ & 17.2 & $-1.71 \%$ & 72.80 & $0.51 \%$ \\
2108 & 2.15 & $514.29 \%$ & 18.6 & $8.14 \%$ & 72.45 & $-0.48 \%$ \\
\hline
\end{tabular}

Based on: BPS Rokan Hulu, 2018, Dinas Pertanian Rokan Hulu, 2018 processed (2019)

In table3, it can be seen that unemployment as a social variable in the planning of the livestock sector in Rokan Hulu fluctuated from 2010 to 2018, as well as other variables. Furthermore, based on the results of data processing or analysis performed by using the 
path analisys technique (path analysis) with the help of SPSS ver. 19, the following results were obtained:

a. Results of data analysis on the empirical causal effect of population number variables (X1) on production (X2) are illustrated by sub-structural equations; $\mathrm{X} 2=\mathrm{pX} 1 \mathrm{X} 2+\mathrm{e}$. Based on the results of the regression output, the path coefficient $(\mathrm{pX} 2 \mathrm{X} 1)=0.883$, with $\mathrm{t}$ count $=5.323$, and t table $=1.648$. This shows that $\mathrm{t}$ count $>\mathrm{t}$ table meaning that the path coefficient is significant. In accordance to the results of the data processing, it can be interpreted that the population (X1) affects on production (X2), meaning that the improvement of the population (good management) can increase livestock production. The path coefficient value is 0.883 . This explains that the population contribution to production is $77.97 \%$ while the remaining $22.03 \%$ is influenced by other factors not included in the estimation model.

b. Results of data analysis on the empirical causal effect of population number variables (X1), production (X2), on the unemployment rate $(\mathrm{X} 3)$ are illustrated by sub-structural equations; $\mathrm{X} 3=\mathrm{pX} 3 \mathrm{X} 1+\mathrm{pX} 3 \mathrm{X} 2+\mathrm{e}$. Based on the results of the regression output, the path coefficient is $\mathrm{pX} 3 \mathrm{X} 2=1.73$ with $\mathrm{t}$ count $=3.789$, while $\mathrm{t}$ table is 1.648 . This indicates that $\mathrm{t}$ count $>\mathrm{t}$ table means that the path coefficient is significant. Path coefficient is $\mathrm{pX} 3 \mathrm{X} 1=-1.41$, with $\mathrm{t}$ count $=-3.07$, while $\mathrm{t}$ table is 1.648. This shows that $\mathrm{t}$ count $<\mathrm{t}$ table means that the path coefficient is not significant. In accordance to the results of the data processing, it can be interpreted simultaneously that livestock production (X2) and population number (X1) affects the unemployment rate (X3). The magnitude of the simultaneous influence is 0.33 , meaning that the variables of livestock production (X2) and population (X1) contribute $33 \%$ to the unemployment rate in Rokan Hulu.

The results of data processing show that $\mathrm{pX} 3 \mathrm{X} 2$ path coefficient value is 1.73 . This indicates that livestock production contributes to unemployment by $29.99 \%$ and while the remaining $69.99 \%$ is influenced by other factors not included in the estimation model. Furthermore, the pX3X1 path coefficient value is 1.45 . Thus, this indicates that land area contributes to the unemployment rate of $19.07 \%$ and the remaining $81.03 \%$ is influenced by other factors not included in the estimation model, meaning that if the population is managed by farmers experiencing a reduction, the number of unemployed has increased. This certainly explains that population and production can affect the unemployment rate in Rokan Hulu district.

c. Results of data analysis on empirical causal influence among livestock population (X1), production (X2) and unemployment rate (X3) on poverty level (X4) are described by sub-structural equation; $\mathrm{X} 4=\mathrm{pX} 4 \mathrm{X} 1+\mathrm{pX} 4 \mathrm{X} 2+\mathrm{pX} 4 \mathrm{X} 3$ + e. Based on the results of the regression output, path coefficient $\mathrm{pX} 4 \mathrm{X} 1$ is -0.009 with $\mathrm{t}$ count -0.13 and table 1.648. This fact reveals that $t$ count $<t$ table means that the path coefficient is not significant. In addition, path coefficient pX4X2 is -0.517 ) with t count -0.683 and t table 1.648 . This fact reveals that $\mathrm{t}$ count $<\mathrm{t}$ table means that the path coefficient is not significant. Moreover, path coefficient pX4X3 is 0.992 with $\mathrm{t}$ count 2.771 and $\mathrm{t}$ table 1.648. This fact reveals that $\mathrm{t}$ count> $t$ table means that the path coefficient is significant. Based on the results of data analysis, it can be interpreted that unemployment rate (X3), livestock production (X2) and population (X1) affect poverty (X4) simultaneously. The magnitude of the simultaneous influence is 0.446 , which means that unemployment variable (X3), duck production (X2) and population (X1) contribute $44.6 \%$ to poverty in Rokan Hulu.

Variable pX4X1 path coefficient value is obtained = -0.517 , meaning that it can be explained that the population contributes to community poverty by $26.7 \%$ and the remaining $73.3 \%$ is influenced by other factors not included in the estimation model, meaning if the population will managed by farmers experiencing a reduction, population of poor people will increase. Then the $\mathrm{pX} 4 \mathrm{X} 2$ path coefficient value was obtained $=-0.009$, explained that livestock production contributed $0,0001 \%$ to the community poverty level and dominantly influenced by other factors not included in the estimation model.

Variable pX4X3 path coefficient value is 0.992. This shows that the rate of unemployment contributes to the poverty rate by $98.41 \%$ while the remaining $1.6 \%$ is influenced by other factors not included in the estimation model. This indicates that if the number of unemployed people increases, the number of people living in poverty will increase as well. This certainly explains that land area, production and unemployment rates can affect poverty in a region.

d. Results of data analysis on empirical causal influence among population (X1), production (X2), unemployment rate (X3), poverty rate (X4), unemployment rate (X4) on HDI (X5) are described by sub-structural equations; $X 5=\mathrm{pX} 5 \mathrm{X} 1$ $+\mathrm{pX} 5 \mathrm{X} 2+\mathrm{pX} 5 \mathrm{X} 3+\mathrm{pX} 5 \mathrm{X} 4+\mathrm{e}$.

Based on the results of the regression output, path coefficient $\mathrm{pX} 5 \mathrm{X} 1$ is -0.382 with $\mathrm{t}$ count -0.325 and $\mathrm{t}$ table 1.648. This fact reveals that $\mathrm{t}$ count $<\mathrm{t}$ table means that the path coefficient is not significant. Furthermore, path coefficient $\mathrm{pX} 5 \mathrm{X} 2$ is -3.96 with $\mathrm{t}$ count -0.284 and $\mathrm{t}$ table 1.648. This shows that $\mathrm{t}$ count $<\mathrm{t}$ table means that the path coefficient is not significant. Moreover, path coefficient $\mathrm{pX} 5 \mathrm{X} 3$ is 0.971 with $\mathrm{t}$ count 1.12 and t table 1.648 . This fact shows that $\mathrm{t}$ count $<\mathrm{t}$ table means that the path coefficient is significant. Meanwhile, path coefficient pX5X4 is -0.643 with t count 0.887 and t table 1.648. This fact reveals that $\mathrm{t}$ count $<\mathrm{t}$ table means that the path coefficient is not significant.

Based on the results of data processing, it can be interpreted that the number of people living in poverty (X4), unemployment rate (X3), livestock production (X2) and population (X1) have an effect on HDI (X5) simultaneously. The magnitude of the simultaneous influence is 0.455 or $45.5 \%$, meaning that the poor population (X4), unemployment rate (X3), livestock production (X2) and land area (X1) contribute $45.5 \%$ to the development of HDI in Rokan Hulu District.

pX5X1 path coefficient value is -0.382 . This means that land area contributes to HDI by $14.59 \%$ and the other $84.5 \%$ is influenced by other factors not included in the estimation model. In addition, pX5X2 path coefficient value is -0.396 . This indicates that livestock production contributes to HDI by $0.06 \%$, which means that the 
dominant factors influencing are not included in the estimation model.

Furthermore, the value of pX5X3 path coefficient is 0.971 . This indicates that the number of unemployed people contributes to HDI level by $84.3 \%$ while the remaining $15.7 \%$ is influenced by other factors not included in the estimation model. This means that the increase of unemployment rate affects HDI of Rokan Hulu District. pX5X4 path coefficient is is 0.643 . This means that poverty rate contributes to HDI level by $41.34 \%$ and the remaining $58.66 \%$ is influenced by other factors not included in the estimation model. This indicates that if the unemployment rate increases, HDI will decrease and vice versa.

e. The results of data analysis on empirical causal influence among livestock population (X1), production (X2), unemployment rate $(\mathrm{X} 3)$, poverty rate $(\mathrm{X} 4)$, unemployment rate (X4) and HDI (X5) on famers' income are illustrated by sub-structural equations; Y1 = pY1X1 + pY1X2 + pY1X3 + pY1X4 + pY1X5 + e.

Based on the results of the regression output, path coefficient $\mathrm{pY} 1 \mathrm{X} 1$ is -0.91 with with $\mathrm{t}$ count -2.67 and $t$ table 1.648. This fact reveals that $t$ count $<t$ table means that the path coefficient is not significant. In addition, path coefficient pY1X2 is 0.329 with t count 0.821 and t table 1.648. This fact reveals that $t$ count $<t$ table means that the path coefficient is not significant. Meanwhile, path coefficient pY1X3 is -0.46 with $\mathrm{t}$ count -0.168 and $\mathrm{t}$ table 1.648 . This fact reveals that $\mathrm{t}$ count $<\mathrm{t}$ table means that the path coefficient is not significant.

Path coefficient $\mathrm{pY} 1 \mathrm{X} 4$ is -0.662 , with $\mathrm{t}$ count -3.167 and $\mathrm{t}$ table 1.648. This fact reveals that $t$ count $>t$ table means that the path coefficient is significant. In addition, path coefficient pY1X5 is 0.492, with t arithmetic 4.499 and t table 1.648 . This fact reveals that $\mathrm{t}$ count $>\mathrm{t}$ table means that the path coefficient is significant.

Based on the results of data processing, it can be interpreted that HDI (X5), the number of people living in poverty (X4), unemployment rate (X3), production (X2) and population (X1) affect the income of the community (Y1) simultaneously. The magnitude of simultaneous influence is 0.609 or $60.9 \%$, meaning that HDI variable (X5), the number of people living in poverty (X4), unemployment rate (X3), livestock production (X2) and population (X1) contribute $60.9 \%$ to farmers' income in Rokan Hulu.

Variable pY1X1 path coefficient value is 0.91 . This means that the number of population contributes to the level of community income by $82.8 \%$, and the remaining $17.2 \%$ is influenced by other factors not included in the estimation model. pY1X2 path coefficient value is $-0,329$. This indicates that livestock production contributes $10.82 \%$ to farmers' income and dominantly influenced by other factors not included in the estimation model.

Furthermore, pY1X3 path coefficient value -0.46 means that the unemployment rate contributes negatively to farmers' income by $21.16 \%$ while the other $78.84 \%$ is influenced by other factors not included in the estimation model. This indicates that if the unemployment rate increases, it will have an effect on the income of duck farmers in Rokan Hulu. pY1X4 path coefficient value -0.662 means that the poverty rate contributes to farmers' income by $43.82 \%$ while the other
$56.18 \%$ is influenced by other factors that are not included in the estimation model. This indicates that if poverty increases, farmers' income will decline.

Variable pY1X5 path coefficient value 0.492 means that HDI contributes to famers' income by $24.21 \%$ while the other $75.79 \%$ is influenced by other factors not included in the estimation model. This indicates that if HDI increases, famers' income will increase as well. This certainly explains that population, production, unemployment rate, poverty level, and HDI affect the income of Rokan Hulu duck farmers.

f. Results of empirical causal analysis data influence population (X1), production (X2), unemployment rate (X3), poverty rate (X4), unemployment rate (X4), HDI (X5) and famers' income (Y1) in regional development (Y2 ), illustrated by sub-structural equations; $\mathrm{Y} 2=\mathrm{pY} 2 \mathrm{X} 1+\mathrm{pY} 2 \mathrm{X} 2$ $+\mathrm{pY} 2 \mathrm{X} 3+\mathrm{pY} 2 \mathrm{X} 4+\mathrm{pY} 2 \mathrm{X} 5+\mathrm{pY} 2 \mathrm{Y} 1+\mathrm{e}$.

Based on the results of the regression output, path coefficient pY2X1 is 0.057 with $t$ count 0.218 and t table 1.648. This fact reveals that $\mathrm{t}$ count $<\mathrm{t}$ table means that the path coefficient is not significant. Meanwhile, path coefficient pY2X2 is 0.207 , with t count 0.623 and t table 1.648. This fact reveals that $\mathrm{t}$ count $<\mathrm{t}$ table means that the path coefficient is not significant. Furthermore, path coefficient pY2X3 is -0.336) with t count -1.592 and t table 1.648. This fact reveals that $t$ count $<t$ table means that the path coefficient is not significant.

Path coefficient $\mathrm{pY} 2 \mathrm{X} 4$ is -0.531 , with $\mathrm{t}$ count -1.759 and $\mathrm{t}$ table 1.648. This fact reveals that $t$ count $>t$ table means that path coefficient is significant. Moreover, path coefficients pY2X5 is -0.170 , with $t$ count -0.822 and t table 1.648 . This fact reveals that $t$ count $<t$ table means that the path coefficient is not significant. Path coefficient $\mathrm{pY} 2 \mathrm{Y} 1$ is 0.257 , with $\mathrm{t}$ count 0.670 and $t$ table 1.648. This fact reveals that $t$ count $<t$ table means that the path coefficient is not significant.

Based on the results of the data processing, it can be interpreted that farmers' income (Y1), HDI (X5), population of people living in poverty (X4), unemployment rate (X3), production (X2) and population (X1) influence labor absorption simultaneously. This becomes an indicator of regional development (Y2). The magnitude of the simultaneous influence is -0.30 or $-30.0 \%$, meaning that the income of society variable (Y1), HDI variable (X5), population of people living in poverty (X4), unemployment rate $(\mathrm{X} 3)$, livestock production $(\mathrm{X} 2)$ and the number of population (X1) contributes $30.0 \%$ to regional development. This is illustrated by the level of employment in Rokan Hulu.

Variable pY2X1 path coefficient value is 0.57 , thus it indicates that the land area contributes to the employment absorption rate of $32.49 \%$ and the remaining $67.51 \%$ is influenced by other factors not included in the estimation model. pY2X2 path coefficient value is 0.207 . This means that the population contributes to employment absorption of by $0.428 \%$. This indicates that there are other dominant factors that are not included in the estimation model.

Furthermore, variable pY2X3 path coefficient value is -0.336 , meaning that the unemployment rate contributes negatively to regional development which is illustrated by the employment 
absorption rate of $11.29 \%$ and the remaining $88.71 \%$ is influenced by other factors not included in the estimation model. This means that if the number of unemployed people increases, the absorption of labor will be very low.

Variable pY2X4 path coefficient value is -0.531 Thus, it can be explained that poverty contributes to the employment absorption rate by $18,2 \%$. The other $81.8 \%$ is influenced by other factors not included in the estimation model. This means that if poverty increases, the absorption of work will decline. In addition, $\mathrm{pY} 2 \mathrm{X} 5$ path coefficient is -0.170 . This indicates that HDI contributes to the employment absorption rate by $2.9 \%$. The other $97.1 \%$ is influenced by other factors not included in the estimation model. This means that if there is a pY2Y1 variable, path coefficient value is 0.257 so that it indicates that duck farmers' income contributes to the development of the district, seen from the absorption of labors by $6.6 \%$ while the other $93.4 \%$ is influenced by other factors not included in the estimation model. This means that if the income of the farmers shows an increase, the absorption of labor as an illustration of regional development will also increase. This certainly indicates that the number of population, livestock production, rates of unemployment, poverty levels, HDI and farmers' income affect regional development as seen from the level of employment in Rokan Hulu District.

If HDI and the absorption of labors increase, regional development will improve as well.

\section{CONCLUSION}

Based on the results of the study, it can be concluded:

1. HDI, total of poor people, unemployment rate, livestock production and population influenced duck farmers' income simultaneously by $60.9 \%$ in Rokan Hulu District.

2. The income level of duck farmers, HDI, the number of people living in poverty, unemployment rate, livestock production and population influenced regional development simultaneously by $30.0 \%$ in Rokan Hulu District, seen from the level of employment.

\section{SUGGESTION}

Based on the results of research studies obtained, the suggestions that can be submitted are:

1. Rokan Hulu government should make efforts to improve public opinion.

2. Rokan Hulu government should make efforts to improve HDI, reduce the number of people living in poverty and unemployed people.

3. Rokan Hulu government should make efforts to increase the productivity of livestock commodities, especially food commodities through a program because it will influence the absorption of labors, and this can be an indicator of regional development in Rokan Hulu.

4. Rokan Hulu government should make efforts to provide employment because the unemployment rate there is still high.

\section{ACKNOWLEDGMENTS}

The Reserach was fully financed by Indonesia Endowment Fund For Education (Lembaga Pengelola Dana Pendidikan/LPDP) tough Doctoral Scholarship Program. The Authors would like to thank head of BPS for allowing the study and his staffs for gathering data, Dean of faculty of Animal Science and staff of Laboratory of Socio Economic of Animal Science Diponegoro University

\section{REFERENCES}

[1] Abdurrahman, 2010. Hasil Evaluasi Program Pembangunan Peternakan Dan Tinjauan Masa Depan Melalui Perspective Analysis. Dinas pertanian dan kehutanan.

[2] Ardi, A . 2016. Keragaman Sifat Kuantitatif Itik Pitalah di Kelompok Tani Syariah Terpadu Nagari Batipuh Baruah Kecamatan Batipuh Kabupaten Tanah Datar. Fakultas Peternakan Universitas Andalas. Badan Penerbit Universitas Andalas. Padang.

[3] Basriwijaya, K. M. Z., W. Sumekar, T. Ekowati, and D. Sunarti. 2018 Correlation Between Motivation And Behavior of Pitalah Duck Farmer (Case Study in Rokan Hulu Regency Riau State) Proceeding of the 1st International Conference on Food and Agriculture. Bali.

[4] BPS, Rokan Hulu Dalam Angka 2018. Rokan Hulu.

[5] Ekowati, T., E. Prasetyo dan H. Oxtovianto. 2005. Manajemen Permodalan Pada Anggota KTTI "Maju Jaya" untuk Pengembangan Usaha Ternak Itik di Kecamatan Brebes Kabupaten Brebes. Prosiding Seminar Nasional dan Teknologi Peternakan.

[6] Garson, D. 2003. Path Analysis. North Carolina State University http://www.mitrariset.com/2009/04/analisis-jalur-path-analysis

[7] Halim, B. 2017. Potensi Dan Strategi Pengembangan Itik Pitalah Di Kabupaten Tanah Datar. Badan Penerbit Universitas Andalas. Padang.

[8] Janiszewski, D. Hanzal, V. Gesek, M. Michalik. D. Dan M., Zawacka. 2018. Carcass characteristics, meat quality, and fatty acid composition of wild-living mallards (Anas platyrhynchos L.) Poultry Science, Vol 97, Februari 2018. Issue Pages 709-715.

[9] Kasim, K, D Salman, A R Siregar, R A Nadja and A Ahmad. 2019. Vulnerability and adaptive strategies on duck breeder in Pinrang District, Indonesia, 1st International Conference on Global Issue for Infrastructure, Environment \& Socio-Economic Development, Makassar, Indonesia

[10] Nadra, U. 2018. Curahan Waktu Kerja Rumah Tangga Peternak Berdasarkan Dimensi Gender dalam Tradisi Batak Toba di Toba Samosir Sumatera Utara. Fakultas Ekonomi Universitas Diponegoro Semarang.

[11] Satrio Y., S.I Santoso, dan A Setiadi. 2016. Analisis Pengembangan Usaha Ternak Itik Di Kecamatan Banyubiru Kabupaten Semarang. Animal Agriculture Journal. Fakultas Peternakan dan Pertanian Universitas Diponegoro. 4(2):8-15

[12] Sumekar, W., Isbandi U. Atmomarsono And I. Susilowati. 2013 Business Performance of Duck Farmers In Brebes Regency Central Java. Journal of the Indonesian Tropical Animal Agriculture. Faculty of Animal and Agricultural Sciences, Diponegoro University. 38 (3) $: 1-18$

[13] Yongky, D. 2016. Struktur Populasi Itik Pitalah Di Nagari Batipuah Baruah Kecamatan Batipuah Kabupaten Tanah Datar. Fakultas Peternakan Universitas Andalas. Badan Penerbit Universitas Andalas. Padang

[14] Welerubun, I. N., A. Setiadi dan T. Ekowati. 2016 Faktor-faktor yang mempengaruhi pendapatan peternak domba kisar di pulau Kisar Kabupaten Maluku Barat Daya. Jurnal Agromedia. 34 (2) : 54-64

[15] Yotopoulos, P.A. and L.J, Lau. 1976. Introduction Food Research Institute Studies, Vol XVI, Wester Book- Journal Press, California.

[16] Zurmiati, W. M. H. Abbas, M. E. Mahata dan R Fauzano. 2018. International Journal of Poultry Science 16 (4): 147-153

\section{AUTHORS PROFILE}

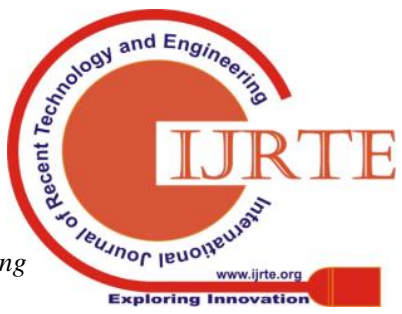


K. M. Z Basriwijaya I am a man who was born on December 19, 1986, I was given the name Kiagus Muhammad Zain Basriwijaya. I was born in Pematang Raya, North Sumatra. started elementary school education at Bawen State 03 Elementary School. Junior High Schools in Surakarta and must live in Islamic boarding schools. I live in a boarding school not only completing Senior high school. I have to continue high school in Ponorogo. Because I was born to an educated family, I went on to college because I wanted to change my family's lifestyle. I studied at Diponegoro University, Faculty of Animal Husbandry and Agriculture, Department of Social Economics, Animal Husbandry and Masters Degree in the Department of Agribusiness, Diponegoro University. Now I am still studying in the 6th semester of my doctorate in Animal Science and working as a permanent lecturer. This is the biography of myself, hopefully, it can be an inspiration for anyone who reads

K. M. Z Basriwijaya, Doctor of Animal Science, and affiliated with Faculty of Animal and Agricultural Sciences, Diponegoro University, Tembalang Campus, and my area of interest is Agricultre.

For contact Semarang 50275 - Indonesia, zainkiagus@ gmail.com

I am W. Sumekar, Doctor of Animal Science, working with Faculty of Animal and Agricultural Sciences ,Diponegoro University, Tembalang Campus, Semarang 50275 - Indonesia, wulan_sumekar@yahoo.co.id

T.Ekowati, Doctor of Animal Science, currently affiliated with Faculty of Animal and Agricultural Sciences, Diponegoro University, Tembalang Campus, I am interested in Animal Sciences. For contact please Semarang 50275 - Indonesia

D.Sunarti, Doctor of Animal Science, affiliated with Faculty of Animal and Agricultural Sciences, Diponegoro University, Tembalang Campus, Semarang 50275 - Indonesia 